THE UNITED STATES ENERGY CRISIS: SUPPLY AND DEMAND ${ }^{\star}$

Vance I. Sailor

Department of Applied Sclence

Brookhaven National Laboratory

Upton, L.I., N.Y. 11973

Presented at:

Science Teachers Assuciation of New York State Annual Conference

Concord Hote1, Kiamesha Lake, New York

October 23, 1972

NOTICE

This report was prepared as an sccount of work sponsored by the United States Government. Noithar the United States nor the United States Atomic Energy Commission, nor any of their employees, nor eny of their contractors, subcontractors, or their employoos, makes any wartanty, oxpress or implied, or auumes any legal liablity or responsibility for the eccuracy, complatenesi or usefulness of iny information, spparatus, product or process disclosed, or represents that its use would not infringe privately owned rights.

*This work was supported by the U.S. Atomic Energy Commission. 


\section{THE APPROACHING STORM}

Energy is that commodity which heats our homes, runs our factories, and propels our transport.

The energy difficulties that we face stem from the fact that we are consuming energy at a staggering rate which continues to increase with no limit in sight. As a result our conventional fuels of today are being depleted rapidly, our atmosphere is choked with combustion products, and we are laying waste to our landscape, to produce, process, distribute, and consume these fuels. When we take a close look at the whole picture it is obvious that we cannot continue in the present pattern for very long. Some major changes must take place.

We are faced with few alternatives, each of which involves various trade-offs. Dr. Robertson and I will be discussing these today.

Instructional Opportunities: I believe there is great need for the public to be well-informed and accurately informed on the matters we will be discussing today. I also belleve that one of the best opportunities for educating the general public is via high school teachers. You have the background to study and grasp the problems, and you have the professional ability to pass this information on to your students and to the community in a manner that they can understand.

There appear to be many interesting instructional opportunities that you might be able to put to work in your class room:

1. The energy problems have both scientific and social components. Regardless of whether you teach physics, biology, social science, earth science, etc, you will find many interesting questions to examine. 
2. The problems are of current interest. Hundreds of news stories, magazine articles, and technical reports are appearing weekly. There is abundant opportunity for students to collect information.

3. Most localities have some kind of dispute involving energy systems--a new oil pipeline, high transmission line, or nuciear power plent--and your classes can quickly become absorbed in the local debate.

4. There is ample opportunity for special student projects. I have attached a list of a few ideas (Appendix A), some of which were tried in various classes that I have taught.

The Arising Crisis: Throughout most of history, mankind derived the energy he needed from simple, natural sources; e.g., the muscle power of humane and donesticated animals, fuel from wood and animal fat, and the force of the winds. Individuals who were fortunate enough to enjoy a few luxuries did so at the expense of their fellow man, by exploiting the efforts of servants or slaves.

Only a few generations ago, mankind began to use appreciable quantities of the fossil-fuels-first coal, la ter petroleum and most recently natural gas. The large-scale exploitation of these fuels coincided with the global population explosion, and the industrial revolution. The use of these fuels bred new uses, technology flourished, and the consumption of fuel increased at an ever-increasing rate. The doubling time for fuel consumption is about 22 years. This means that over the span of our lifetimes each of us will witness an eight-fold increase in the use oL energy! 
You don't have to be a mathematical genius to see that this growth rate cannot continue. The earth has finite resources. Someday they will a 11 be gone. When consumption doubles every 22 years, that "someday" is not far away, at least for certain resources.

Our Increasing Dependence on Energy: The changes in our patterns of living, the processes of urbanization and suburbanization have made each one of us more critically dependent on a regular uninterrupted supply of energy:

1. Our soclety depends on Intensive use of energy for iis productivity. It is a key ingredient to our capacity to earn wages.

2. Our society depends on energy to move the necessities of life to the densely settled areas. The whole web of urban existence would collapse if energy supply were suddenly cut-off. In a large city the loss of electricity is instantly a serious matter. If prolonged for more than a few hours it becomes a civil disaster.

3. The growth pattern of suburbia has made the suburban family totally dependent on the automobile, and hence, on the fuel to propel it.

Energy Conservation: We are all aware that some uses of energy are wasteful, frivolous, Inefficient, extravagant, etc. One reason that this is true, is that energy has always been a very inexpensive commodity in the U.S. Many people point out that the price of energy has been artifically low because we do not include many important costs in the price we pay, e.g., the costs of damage from air pollution is not included in the price 
we pay for a gallon of fuel oil for our home furnace. If these external costs were included, the price of fuel would increase substantially. Actually the costs of some of the environmental clean-up efforts will eventually be included in the price you pay for energy.

Environmental clean-up costs and fuel shortages will both force prices upward. Rising prices will force us to use energy more wisely and more efficiently. However, it might not be wise for us to watt for rising prices to force us to be more frugal with our energy resources. The power required to operate various household devices is gtven in Appendix B. Because of the rapid growth of uses, the restraining forces of the economic market-place might not respond fast enough to avert a serious crisis of energy shortage. I do not mean to imply that we will get up some morning and find that energy "cupboard is bare," although some localized shortages will develop suddenly from time to time. The most serious aspect of the problem is a steady and worsening squeeze for cheap resources, which force energy prices steadily upward beyond tolerable limits. Such a crisis could become an economic and social disaster.

We need to develop a national energy policy to guide our actions in the years inmediately ahead. To better understand the complexities of the problem we must look at some data. Let us begin with the U.S. energy budget.

\section{UNITED STATES ENERGY BALANCE}

Last year--1971--Americans consumed an amount of energy equivalent to $69 \times 10^{15} \mathrm{Btu} .{ }^{(1)}$ If you are like I am, your mind does not work too well in terms of British thermal units (Btu's) particularly in powers of 
$10^{15}$. Even if $I$ express this huge amount of energy in terms of more familiar units, it is still hard to grasp, e.g., the 1971 consumption is equivalent to 2.6 billion tons coal--this would make a pile big enough to cover Manhattan Island to a depth of 193 feet and 9 inches; or $69 \times 10^{15}$ Btu is equivalent to 12.3 billion barrels of oil--which would fill a tank a mile in diameter and 0.6 miles high.

The sources of energy for the U.S. are shown in Table I. To be consistent with tradition, I reluctantly clte most data in terms of Btu's. (See Appendix C for conversion factors between various units.) Often the quantity $10^{18}$ Btu is referred to as Q. Thus our total 1971 consumption was $69 \mathrm{mi} 111-\mathrm{Q}$. The world consumption was only three times larger. (2) In other words, at the present time we consume almost exactly $1 / 3$ of the world's energy, even though we have only $5.6 \%$ of the world's population. The quancities of energy which I have cited do not include the muscle power of human beings and work animals. of course, many countries of the world depend heavily on such primitive sourcess.

There is a strong correlation between energy usage and economic affluence. Workman who command more energy produce more goods and thus receive higher pay. In turn, they can afford to buy more energy for their family comfort and leisure activities. This is illustrated in Fig. 1 which shows the relationship between per capita national income and per capita energy usage. (2) The enhancement of the economic status of the world's masses, implies an enormously increased energy usage.

As can be seen in Table I, the bulk of our energy was supplied by natural gas and petroleum. Together they supplied more than $77 \%$ of our energy. Natural gas and natural gas 1 iquids supplied $36.4 \%$ of the total-almost as much as crude oil. 
Nuclear power supplied less than $0.6 \%$ of the 1971 gross energy input. For comparison I have included an estimate of the energy derived from wood and wood products burned as fuel. As you can see, wood provided us with about twice as much energy as was obtained from nuclear fission. However, the small nuclear contribution is growing at a very large rate--a $68 \%$ increase from 1970 to 1971 --and its contribution will almost double during 1972. In some areas of the country the nuclear share is already quite significant, e.g. In southern New England about $35 \%$ of the electricity was generated in nuclear plants. Later this morning $\mathrm{Dr}$, Robertson and $\mathrm{I}$ will talk in more detail about nuclear power plants and their public health implications.

The Need to Import: Unfortunately the U.S. Is no longer self-sufficient in energy supply. In 1971 we had to import slightly more than $10 \%$ of our total energy. Most of this was in the form of petroleum from Venezuela and Canada. The import data are given in Table II. For the past several years this has been increasing. The National Petroleum Council estimates that by 1985 , almost $30 \%$ of the energy we consume will be imported. Their predictions are illustrated in Fig. 2. (3) Ten years ago we were a net exporter of energy. Th1s change in status--our increasing dependence on imported oil has rather ominous implications in regard to foreign policy and international trade balance. Our Domestic Energy Resources: One of the reasons for our need to import oil is that our domestic production of petroleum and natural gas can no longer keep pace with demand. Dr. M. King Hubbert of the U.S. Geological Survey has discussed the world energy resources in a Scientific American 
article. (4) He argues that the complete production cycle of crude oil and natural gas will pass through a cycle as shown in Fig. 3. (5) According to Hubbert's estimates we are close to the peak of domestic crude ofl production--probably already past the half-way point.

Table III compares the estimated remaining recoverable resources with the 1971 production and the cumulative production through 1971 . The crude oil resource estimate by the American Petroleum Institute is more optimistic than Hubbert. It is my personal inclination to use Hubbert's estimate.

Several things are apparent from Table III. Both petroleum and natural gas will not last much longer. In 25 or 30 years, they will be gone for the most part. We have large resources of coal and uranium-enough to meet the needs for several centuries. However, if we are to make much greater use of these resources we face several difficult problems.

If coal is selected as the replacement for ofl and natural gas, coal production must be increased tenfold or twentyfold by the end of the century. This would exact a frightful environmental toll. Also means must be found to expand production capacity--at great capital costs--and expand the working force. Most of the coal east of the Mississippi has high sulfur content. We have no practical technology today to remove sulfur from the combustion products. Coal can be gasified to produce a substitute for natural gas. The cost is high-several times the present cost of natural gas--but, no doubt, twenty years from now a large fraction of our gas will come from coal. Several pilot plants are testing various methods of coal gasification. In this case, the sulfur can be removed. 
The growth of nuclear enexgy will be limited by the capacity of the nuclear industry to expand. It is estimated that nuclear power can satisfy about $1 / 3$ of our energy needs by the yeax $2000 \mathrm{AD}$. It should be noted that nuclear plants produce only electricity which is not suited for most transportation needs. Methods must be found to produce synthetic liquid fuels from nuclear power plants. At Brookhaven we are working on one such possibility--the production of hydrogen fuels from water. The problems which must be solved are primarily economic. We believe that safety problems in handling large quantities of hydrogen are essentially solved al ready.

Alternative Future Sources: Two other energy resources hold interesting promise--solar energy and fusion. Both of these need intensive research effort before they can be put to practial use. Study panels, (6) which have examined the situation very thorough? $y$, conclude that the federal government should invest large sums of research money in the effort to develop these resources, starting at once.

The U.S. has large deposits of oil shale which can yield a form of crude oil. Difficulties in exploiting this resource are similar to coal-environmental impact and costs.

\section{ELECTRICITY}

About 25\% of our gross input energy is used to generate electricity. Only about $1 / 3$ of the input can be converted to electricity, the remaining $2 / 3$ is waste heat--thermal pollution. The demand for electricity is increasing faster, than for other forms of energy. About every ten years the demand doubles (Fig. 4). Part of the reason for this is that many consumers are converting from other fuels to electricity, e.g., home heating and factories. 
The Steam-Electric Generating Plant: Most electricity used in the U.S. is produced in steam-electric generating plants. The principle of operation is shown in Fig. 5. Steam is produced from a source of heat--from burning coal, or oil, or from a nuclear reactor. The steam drives a turbine-generator to produce electricity. The steam at the exhaust end of the turbine must be condensed by using large quantities of cooling water. About $2 / 3$ of the heat from the fuel is discharged into the cooling water. The heat balance for a 1000 wWe plant is shown in Fig. 6. The best coal-fired plants have a net efficlency of about $38.6 \%$ whereas the typical nuclear plants are about $33 \% . \quad$ The nuclear plant discharges about $50 \%$ more waste heat to cooling water.

The local impact of waste discharge can be reduced by installing a cooling tower on the condenser cooling discharge. These are not without disadvantage because they are big and ugly (Fig. 7), and their operation causes some local effects such as fogging and icing. Also, they are costly to build and operate--thus, they mean more expensive electricity.

\section{ENVIRONMENTAL EFFECTS}

The production and use of energy has many undesirable environmental effects. These include destruction of land from mining, water pollution from oil spills, air pollution, and noxious waste products. I will limit my discussion to air pollution.

\section{Air Pollution from Transport: By far the worst polluter of 211 is the} automobile. The problem is increasing because the number of vehicles is increasing (see Fig. 7), and the total amount of fuel being consumed is increasing (see Fig. 8). (7) New EPA emissions standards are designed 
to reduce air pollution from vehicles. It is too early to predict how successful the regulations will be. Unfortunately, the anti-emission devices will reduce mileage. The real solution to this proble $m$ is to make cars smaller and reduce the use of automoblles.

The total quantities of air pollutants from transport is summarized in Table IV. (8) Carbon dioxide is not noxious but there is concern about long-term clitiatological effects as the $\mathrm{CO}_{2}$ content of the atmosphere increases. Carbon monoxide, $\mathrm{CO}$, is a serious problem in urban areas and the nitrogen oxides, NO $x$, produce photochemical smogs which are very injurious to the health.

Home Heating: Fumaces in homes and buildings contribute to air pollution. Usually these units are not adequately designed and malntainer: to minimize emissions (see Table v). (8)

Air Pollution from Industry and Steam Electric Generating Plants: The chimneys of our factories and power plants emit large quantities of pollutants. These are summarized in Table VI. ${ }^{(8)}$ The oxtdes of sulfur and nitrogen constitute the worst problems.

\section{AIR POLLUTION: EMISSION-DOSE RELATIONSHIP}

There is still much to be learned about the relationship between pollutants that are discharged into the air, and the dose that people receive. The movement of pollutants through the atmosphere depend on weather conditions, height of discharge, and many complex chemical reactions. At this time, it is impossible to write down a simple formula which will describe the concentration of a pollutant in terms of the various sources of emission.

Dr. Robertson will discuss the health effects of air pollutants. 


\section{REFERENCES}

1. U.S. Bureau of Mines, "U.S. Energy Use at New High in 1971," News release, March 31, 1972. Copies may obtained from Bureau of Mines, Department of the Interior, Washington, D. C. 20545.

2. United Nations Statistical Yearbook 1971, United Nations, New York, 1972 .

3. U.S. Energy Outlook, An Initlal Appraisa 1, 1971-1985, Vol. I, The National Petroleum Council, Washington, D. C. 1971.

4. M. King Hubbert, The energy resources of the earth, Sci. Amer. 224, No. $3,60-70$, Sept. 1971 .

5. M. KIng Hubbert, Energy Resources, Chapter 8, Resources and Man, National Academy of Sciences, W. H. Freeman \& Co., San Francisco, (1969).

6. Office of Sclence and Technology (of the White House), Assessment of Energy Technology, 1972, (no reports issued to the public at the present time).

7. Data from, 1971 Automoblle Facts and Figures, annual publication which can be obtained free by writing to Automobile Manufacturers Association, Inc., 1619 Massachusetts Ave., NH, Washington, D. C.

8. Data obtained from Environmental Protection Agency, Washington, D. C. 
OTHER REFERENCES THAT ARE NOT TOO DIFFICULT TO OBTAIN

Chase Manhattan Bank, Outlook for Energy in the United States to

1985, request from J. D. Emerson, Chase Manhattan Bank, 1 Chase

Manhattan Plaza, New York, New York 10015.

Fall 1972, series of articles on energy resources in Science,

(Journal of the AAAS).

D. Merriman, The calefaction of a river, Sci. Amer. 222, No. 5, 42-52, May 1970.

W. C. Gough and B. J. Eastlund, The prospects of fuston power, Sci. Amer. 224, No. 2, 50-64, Feb. 1971.

G. T. Seaborg and J. L. Bloom, Fast breeder reactors, Sct. Amer 223, No. 5, 13-21, Nov. 1970 .

D. J. Rose, Controlled nuclear fusion status and outlook, Science 172, No. 3985, 797-808, May 21, 1971.

Your Congressman, the EPA, the FPC, the Bureau of Mines, the ABC, and local utilities will provide you with much information, if asked. 
TABLE I

1971 U.S. ENERGY CONSUMPTION ${ }^{(a)}$

\begin{tabular}{lcc} 
Energy source & \multicolumn{2}{c}{ Consumption } \\
Coal & $\frac{\left(10^{15} \text { Btu) }\right.}{12.560}$ & $\frac{\text { Percent }}{18.2}$ \\
Petroleum (Crude oil) & 27.940 & 40.5 \\
Natural Gas (Lijuids) & 2.552 & 3.7 \\
Natural Gas (Dry) & 22.734 & 32.9 \\
Hydropower (b) & 2.833 & 4.1 \\
Nuclear (c) & 0.391 & 0.57 \\
Wood (d) TOTAL & $(20.8)$ & -- \\
\cline { 2 - 3 } & 69.010 &
\end{tabular}
(a) Data taken from Ref. 1.
(b) Theoretical Input computed at 10,494 Btu/kWh.
(c) Nuclear fisston heat input computed at 10,660 Btu/kWh.
(d) Estimate of energy derived from wood used as fuel. 
TABLE II

1971 U.S. SOURCES OF ENERGY ${ }^{a}$ (in units of $10^{15} \mathrm{Btu}$ )

Domestic

Energy source

COAL

PETROLEUM (CRUDE AND

REFINED

NATURAT GAS (WET)

HYDROPOWER ${ }^{b}$

NUCLEAR

TOTALC

NET IMPORT production Import Export

$\begin{array}{lll}14.154 & 0.002 & 1.645 \\ 19.558 & 8.291 & 0.474\end{array}$

$\begin{array}{lll}24.871 & 0.954 & 0.083\end{array}$

$\begin{array}{lll}2.796 & 0.074 & 0.037\end{array}$

$\frac{0.391}{61.770} \frac{0}{9.321} \frac{?}{2.239}$

7.082

PERCENT OF ENERGY IMPORTED : $d$ 10.3\%

a) Data from Ref. 1 .

b) Data from FPC. Computed at rate of $10,494 \mathrm{Btu} / \mathrm{kWh}$.

c) Totals will disagree with Table I because stockpile net withdrawals are not included.

d) Based on $69.010 \times 10^{15}$ Btu, 1971 consuption. 


\section{Estimated Ultimate Recoverable Energy \\ Resources of the United States}

The 1971 domestic production is compared with the cumulative production through 1971 and the estimated remaining recoverable resources.

\begin{tabular}{|c|c|c|c|}
\hline Commodity & $\begin{array}{l}1971 \text { Domestic } \\
\text { production } \\
\left(10^{15} \mathrm{Btu}\right)\end{array}$ & $\begin{array}{l}\text { Cumulative } \\
\text { production } \\
\text { through } 1971 \\
\left(10^{15} \mathrm{Btu}\right)\end{array}$ & $\begin{array}{l}\text { Estimated remaining } \\
\text { recoverable resources }\end{array}$ \\
\hline COAL & 14 & 1069 & 32,200 \\
\hline PETROLEUM & 20 & 540 & 555 \\
\hline NATURAL GAS (WET) & 25 & 480 & 1,094 \\
\hline OIL SHAIE & Neg. & Neg. & 1,066 \\
\hline URANIUM $(<15 / 1 b)$ & $-\infty$ & - & 162,000 \\
\hline
\end{tabular}




\section{TABLE IV}

Bmissions of Air Pollutants from Transportation

\begin{tabular}{|c|c|c|c|c|c|c|c|}
\hline Fuel & $\mathrm{CO}_{2}$ & co & $\mathrm{SO}_{2}$ & $\mathrm{NO}_{\mathrm{x}}$ & $\begin{array}{l}\text { Partic- } \\
\text { ulates }\end{array}$ & $\begin{array}{l}\text { Hydro- } \\
\text { carbons }\end{array}$ & $\begin{array}{l}\text { Alde- } \\
\text { hydes }\end{array}$ \\
\hline \multicolumn{8}{|c|}{$\begin{array}{l}\text { (BILLION POUNDS PER YEAR) } \\
\text { YEAR } 1969 \text { (ACTUAL) }\end{array}$} \\
\hline Gasoline & 1570 & 180.2 & 0.422 & 15.4 & 0.75 & 31.6 & $?$ \\
\hline DLese1 Fuel & 231 & 2.20 & 0.264 & 3.51 & 0.128 & 0.361 & 0.030 \\
\hline Jet Fue 1 & 311 & 2.24 & 0.171 & 0.431 & 0.688 & 1.46 & 0.044 \\
\hline \multicolumn{8}{|c|}{ YEAR 1977 (ESTIMATED) } \\
\hline Gasoline & 1750 & 163.3 & 0.47 & 14.33 & 0.834 & 21.13 & $?$ \\
\hline Diesel Fuel & 504 & 4.80 & 0.575 & 7.65 & 0.279 & 0.788 & 0.065 \\
\hline Jet Fue1 & 745 & 5.35 & 0.41 & 1.03 & 1.645 & 3.50 & 0.105 \\
\hline
\end{tabular}




\section{TABLE V}

Emissions of Alr Pollutants from Home and Commerclal Heating

\begin{tabular}{|c|c|c|c|c|c|c|c|}
\hline FUEL & $\mathrm{CO}_{2}$ & $\mathrm{CO}$ & $\mathrm{SO}_{2}$ & NO & $\begin{array}{l}\text { Partic- } \\
\text { ulates }\end{array}$ & $\begin{array}{l}\text { Hydro- } \\
\text { carbons }\end{array}$ & $\begin{array}{l}\text { Alde- } \\
\text { hydes }\end{array}$ \\
\hline
\end{tabular}

(BILLION POUNDS PER YEAR)

YEAR 1969 (ACTUAL)

$\begin{array}{llllllll}\text { Gas } & 873 & 0.132 & 0.004 & 0.426 & 0.127 & 0.053 & 0.067 \\ \text { O11 } & 961 & 0.116 & 3.46 & 1.00 & 0.498 & 0.121 & 0.079 \\ \text { Coa1 } & 116 & 0.211 & 0.80 & 0.125 & 0.084 & 0.062 & 0.0001\end{array}$

YEAR 1977 (ESTIMATED)

$\begin{array}{llllllll}\text { Gas } & 878 & 0.139 & 0.004 & 0.445 & 0.132 & 0.055 & 0.070 \\ 011 & 972 & 0.120 & 3.51 & 0.998 & 0.501 & 0.122 & 0.080\end{array}$


TABLE VI

Emissions of Alr Pollutants from

Fossil-fueled Steam-Electric Plants

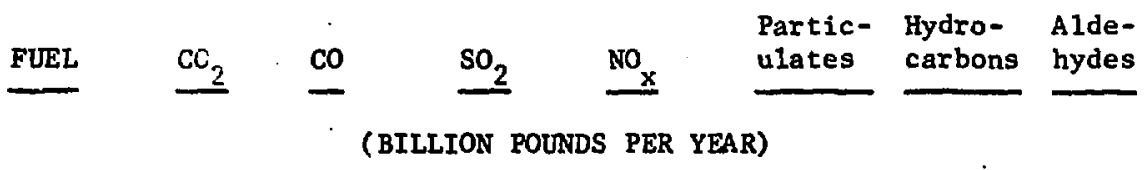

YEAR 1969 (ACTUAL)

$\begin{array}{lrllllll}\text { Gas } & 439 & 0.001 & 0.002 & 1.36 & 0.052 & 0.139 & 0.010 \\ \text { 011 } & 272 & 0.0003 & 3.85 & 1.12 & 0.086 & 0.021 & 0.011 \\ \text { Coal } & 1660 & 0.297 & 31.8 & 6.02 & 7.83 & 0.090 & 0.001\end{array}$

YEAR 1977 (ESTIMATED)

$\begin{array}{lccccccc}\text { Gas } & 466 & 0.002 & 0.002 & 1.17 & 0.055 & 0.148 & 0.011 \\ \text { 011 } & 529 & 0.001 & 2.46 & 1.68 & 0.168 & 0.040 & 0.022 \\ \text { Coal } & 2140 & 0.383 & 11.9 & 7.32 & 6.81 & 0.115 & 0.002\end{array}$


NATIONAL PER CAPITA INCOME (1970 U.S. DOLLARS)

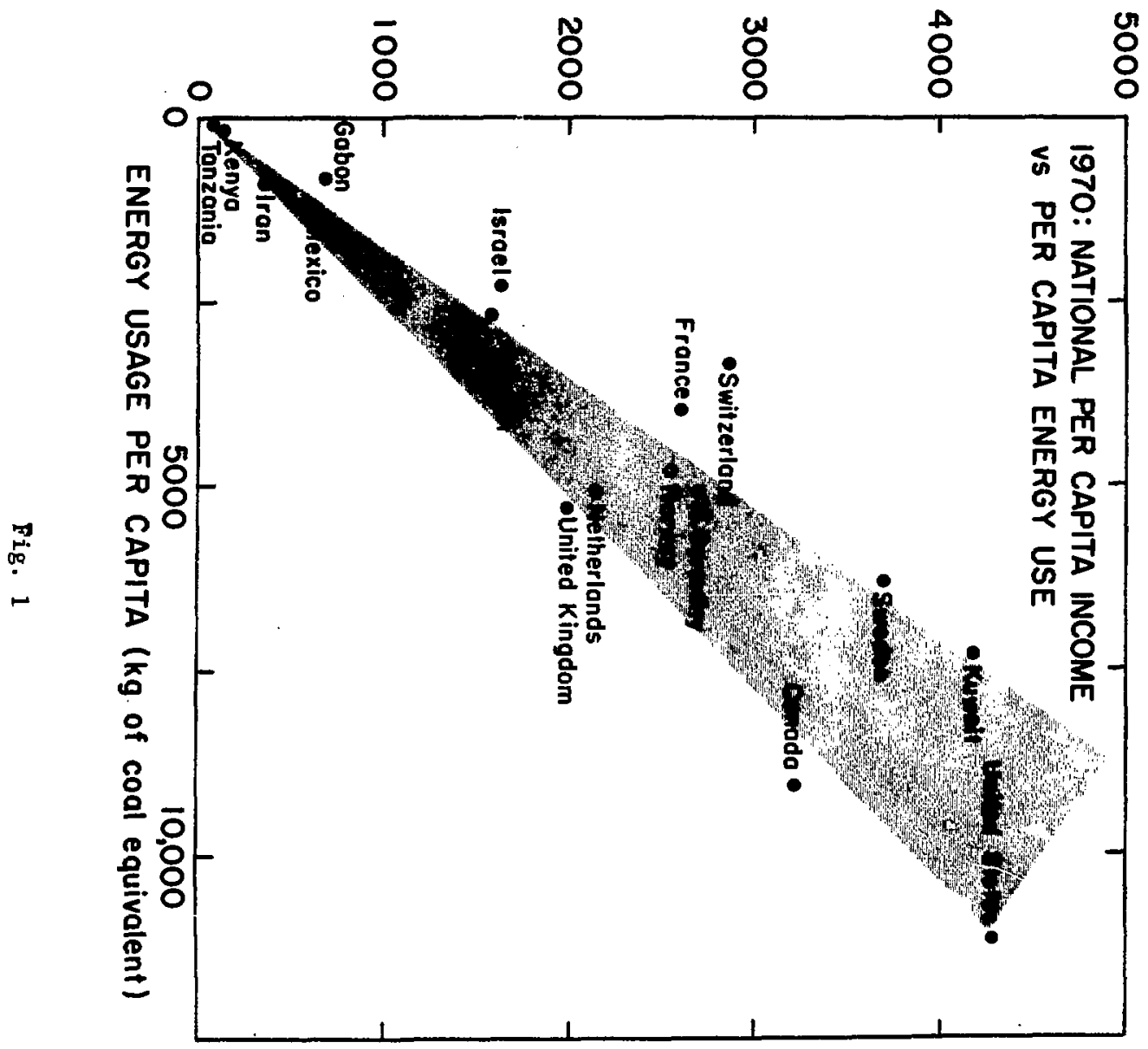




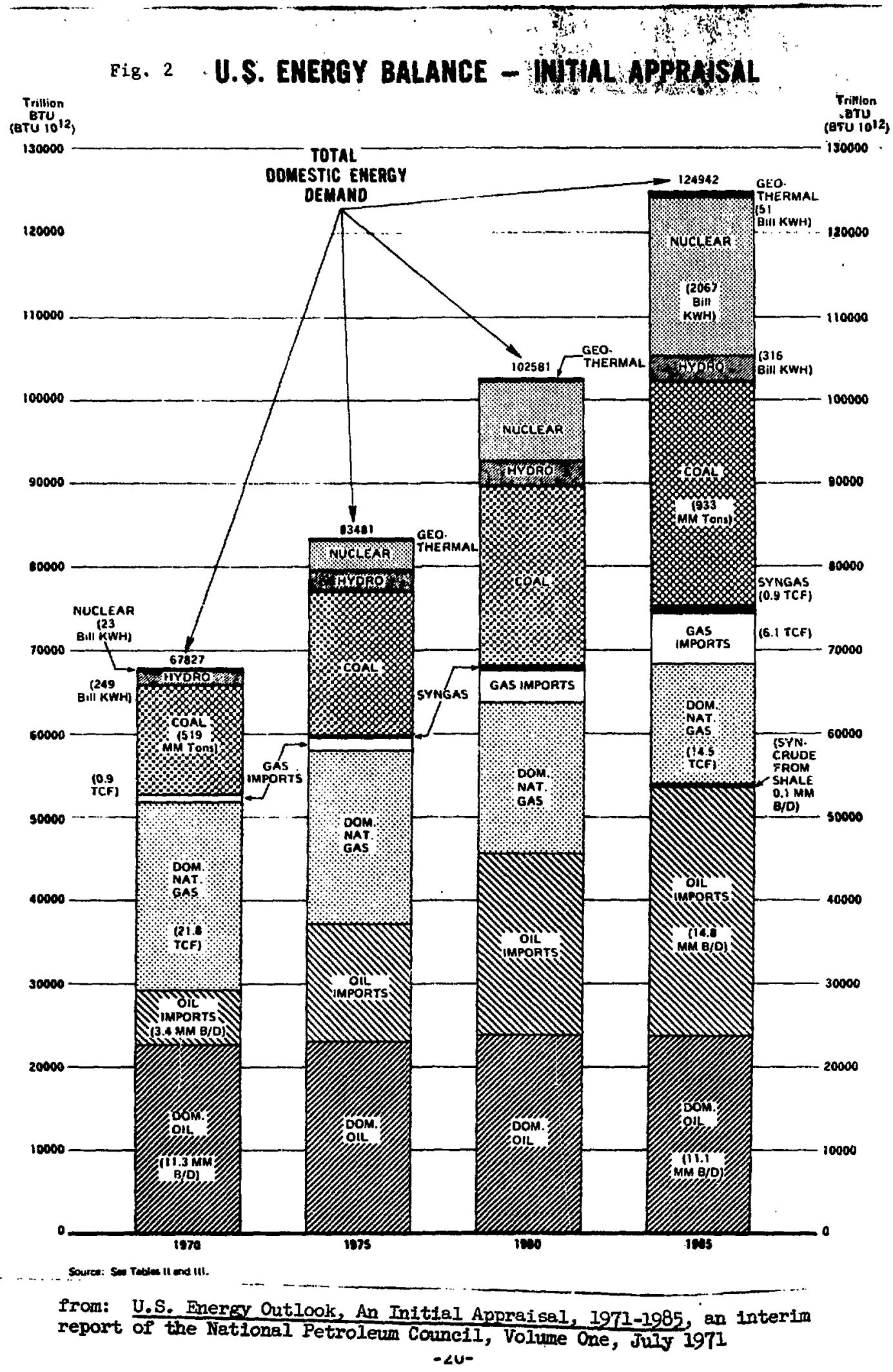




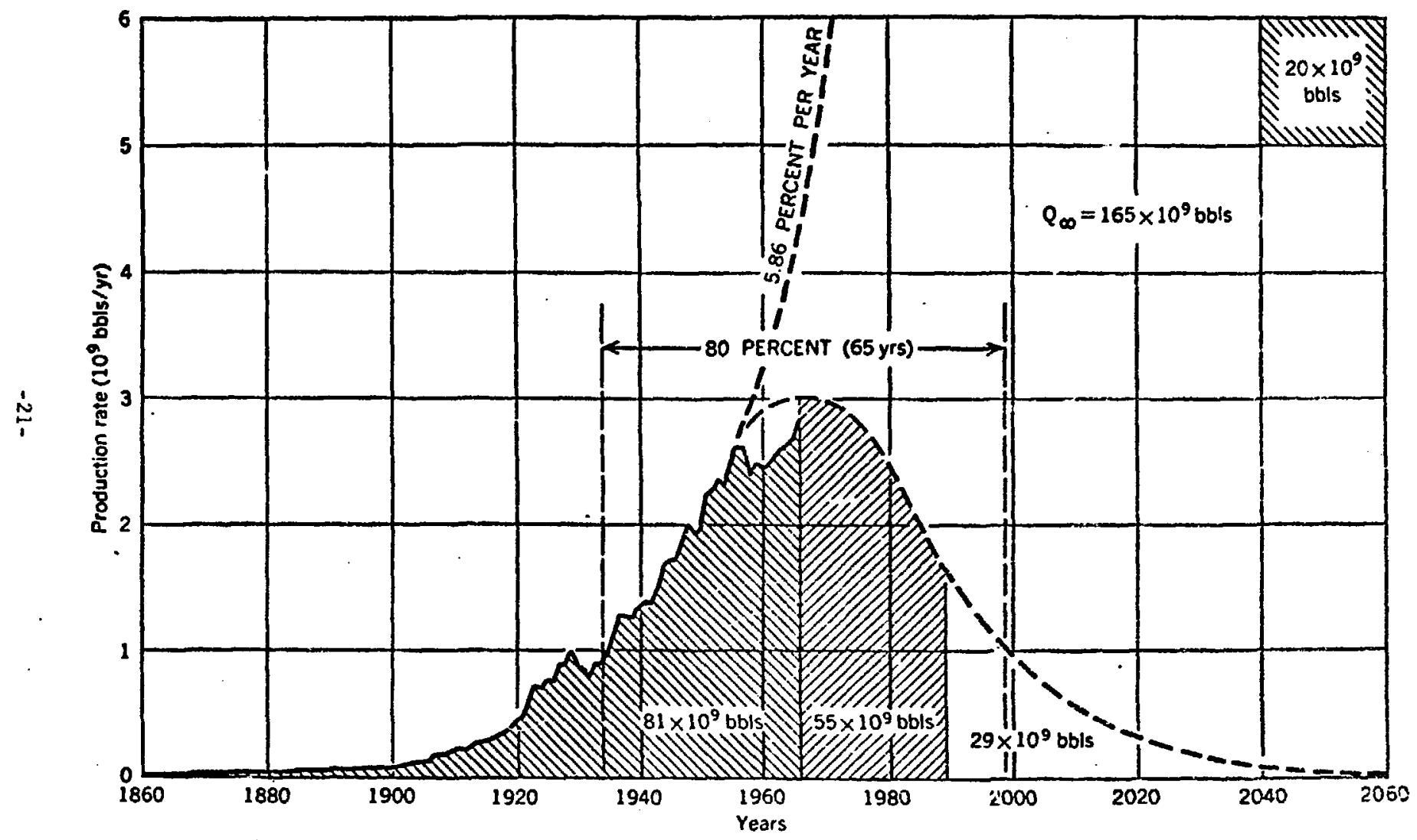

Fig. 3 Total Production Cycle for North American Crude 0 il. (Curve taken from M. K. Hubbert, ref. 5). 


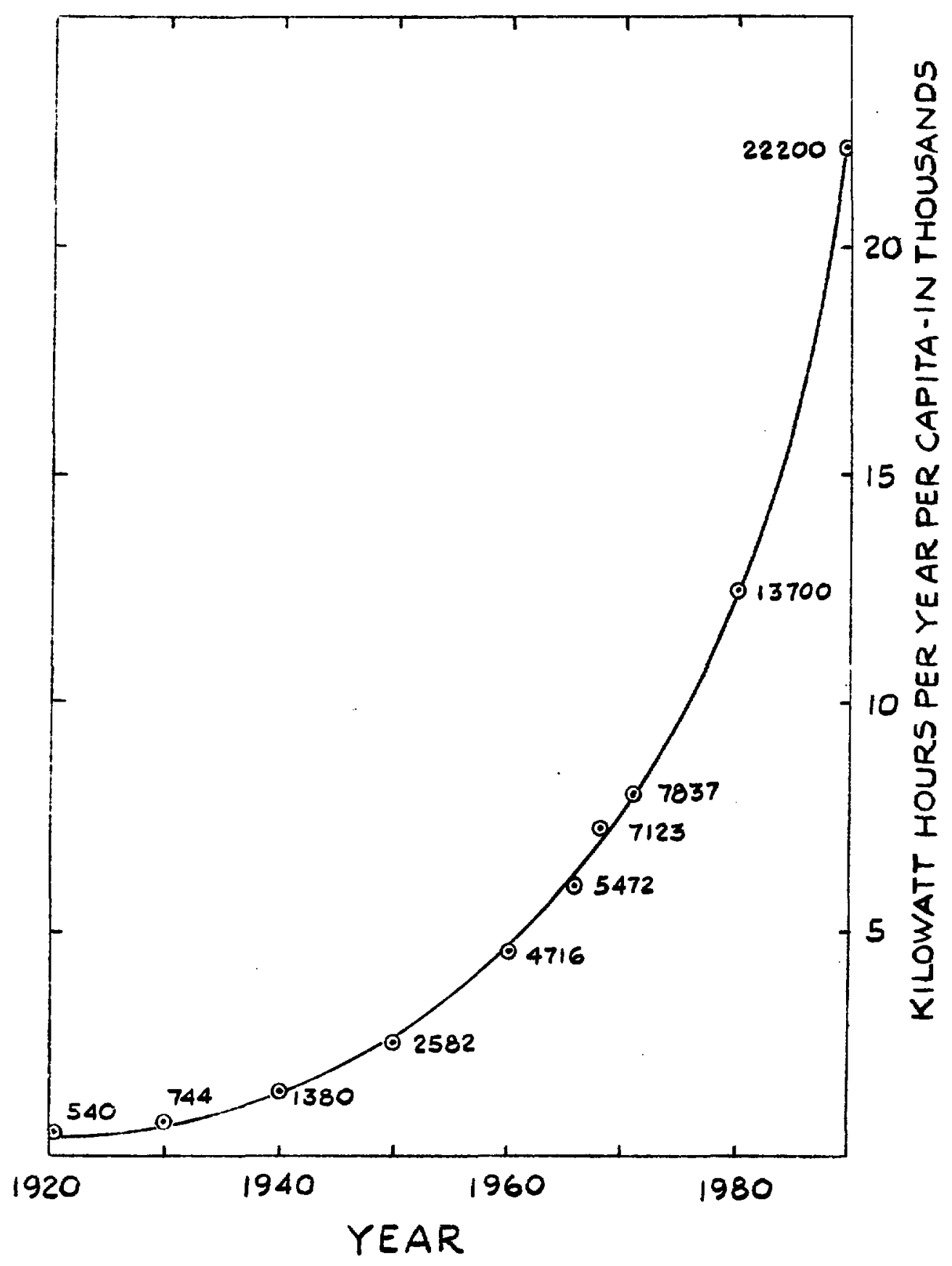

F1g. 4 GROWTH OF PER CAPITA

Electricity Consumption

United States 


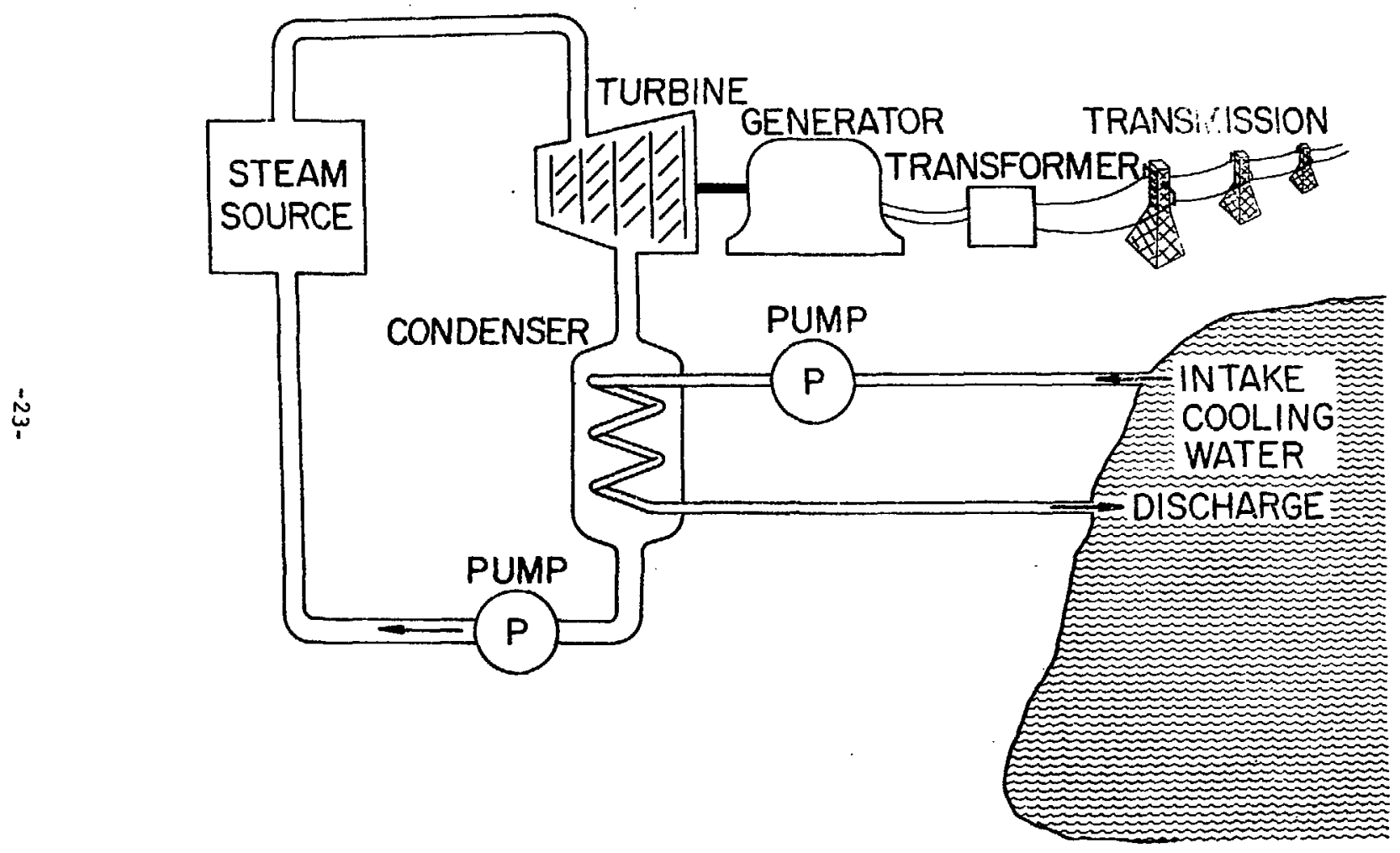

Fig. 5 
HEAT REJECTED BY TYPICAL PLANTS

(1000 MWE NET OUTPUT)
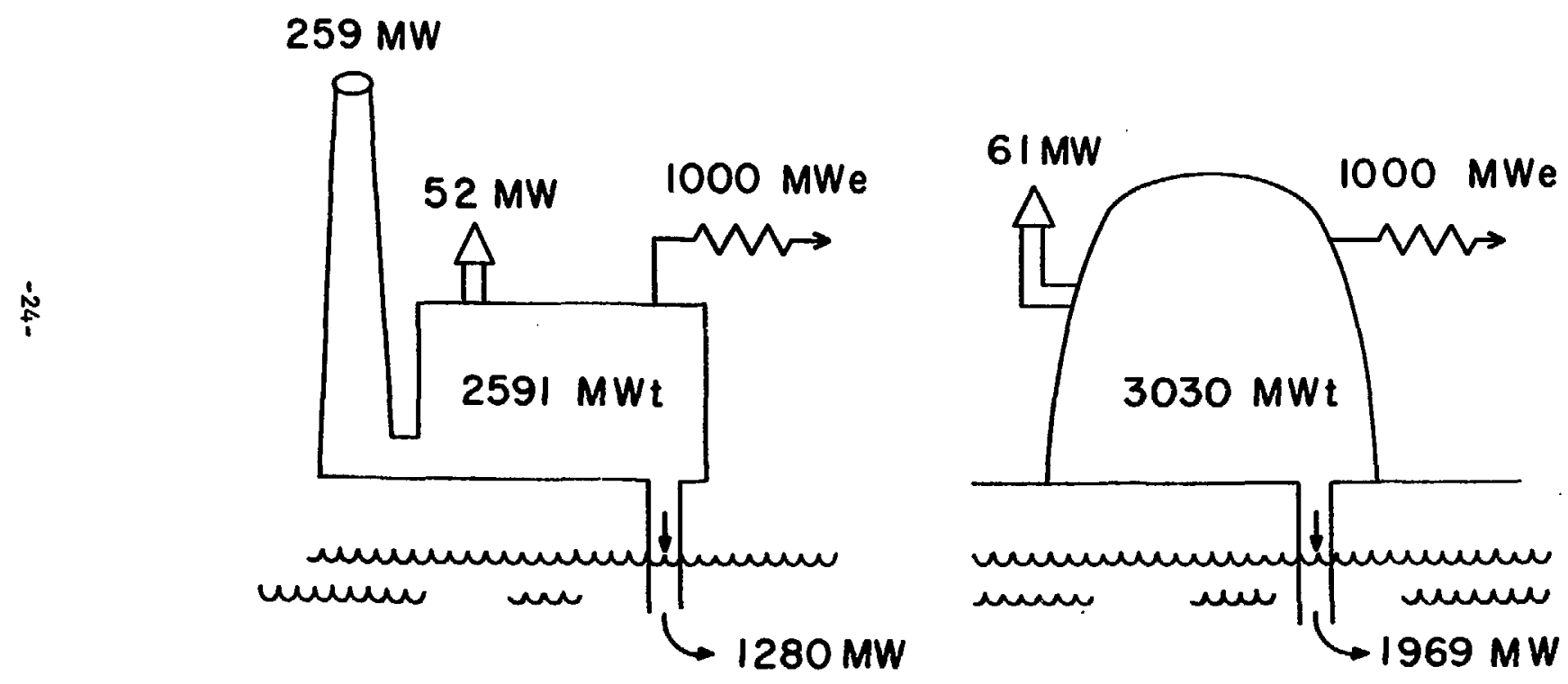

FOSSIL

$\epsilon=38.6 \%$

NUCLEAR

$\epsilon=33 \%$ 


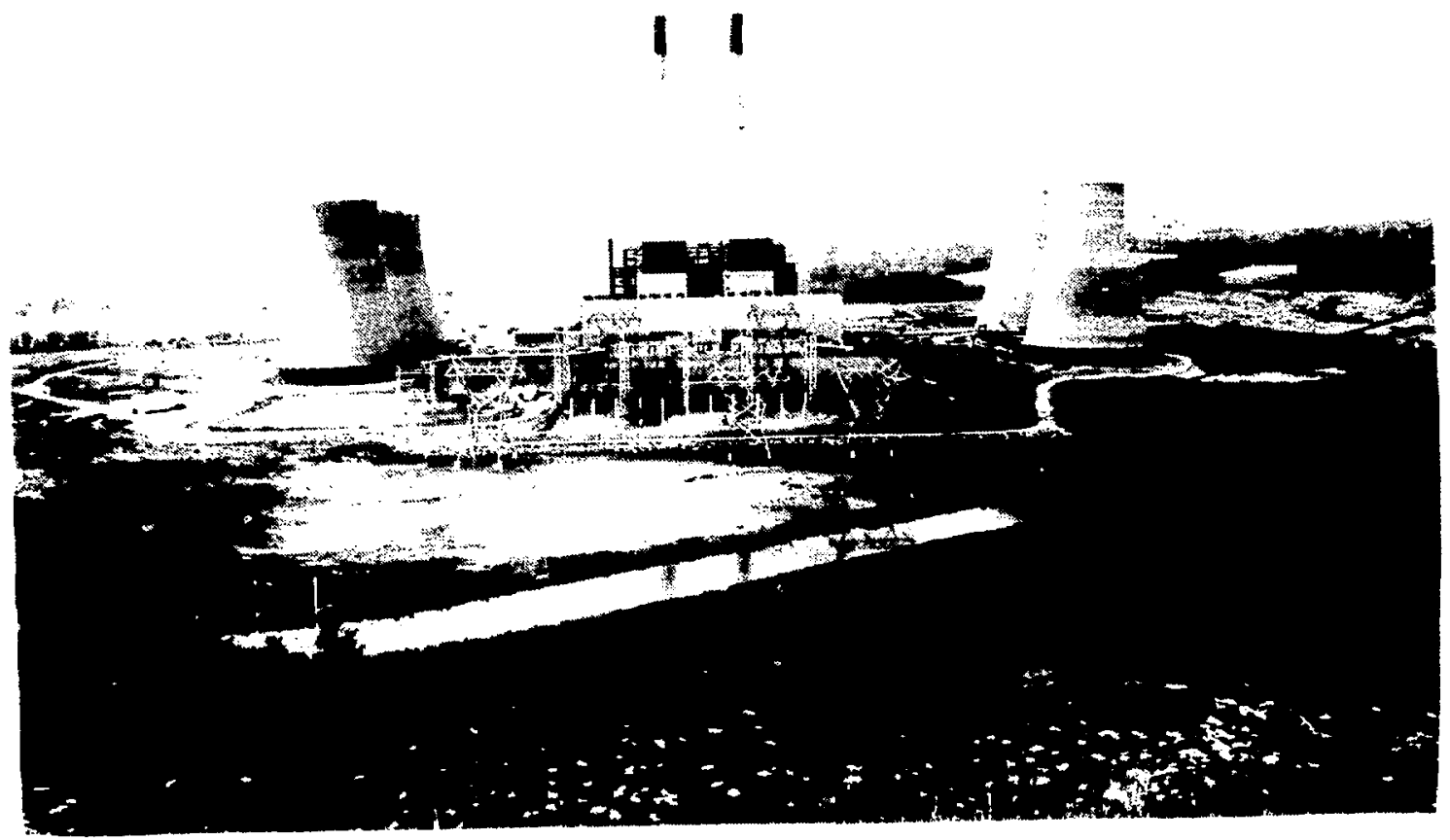

HGURE 7 


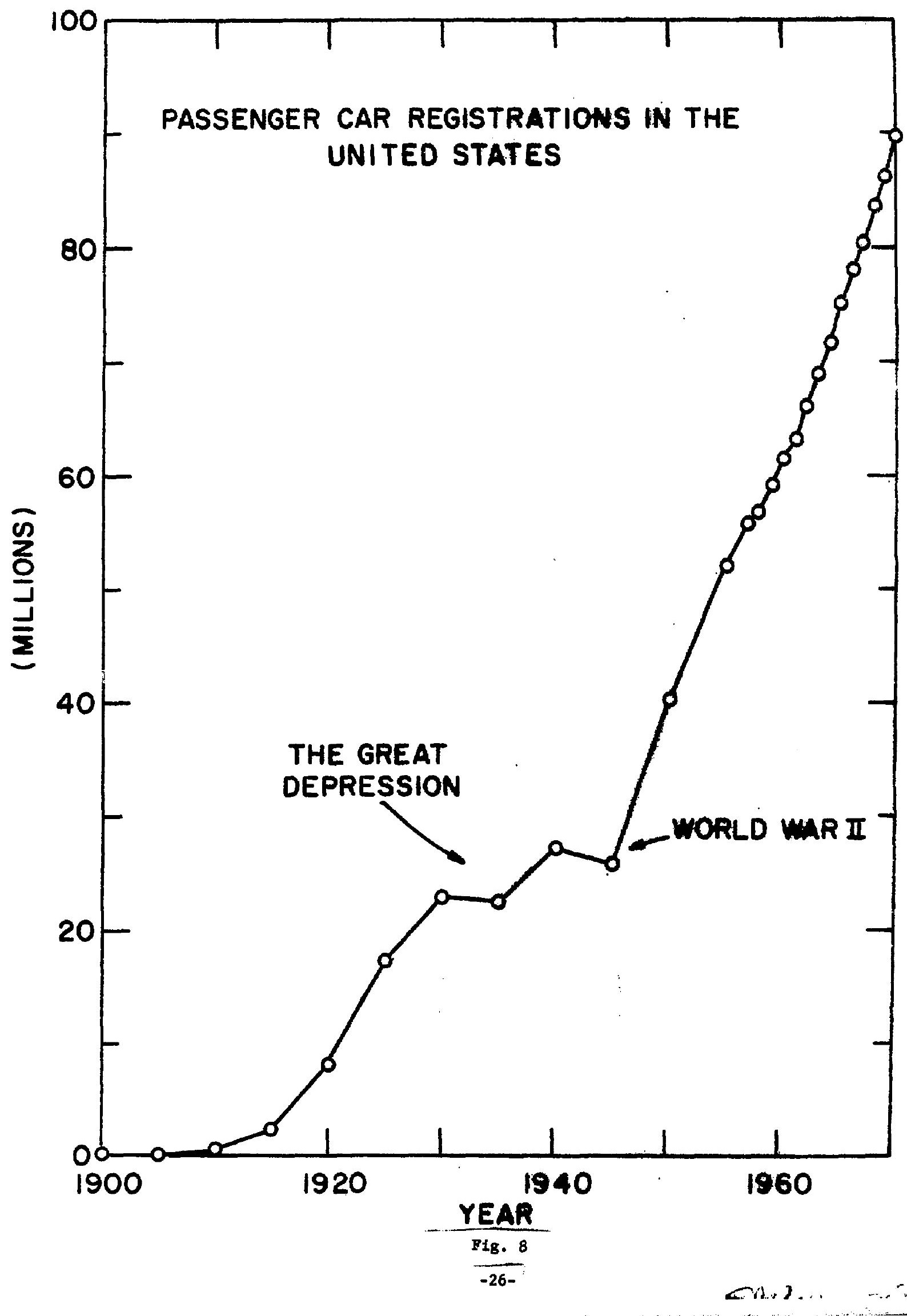




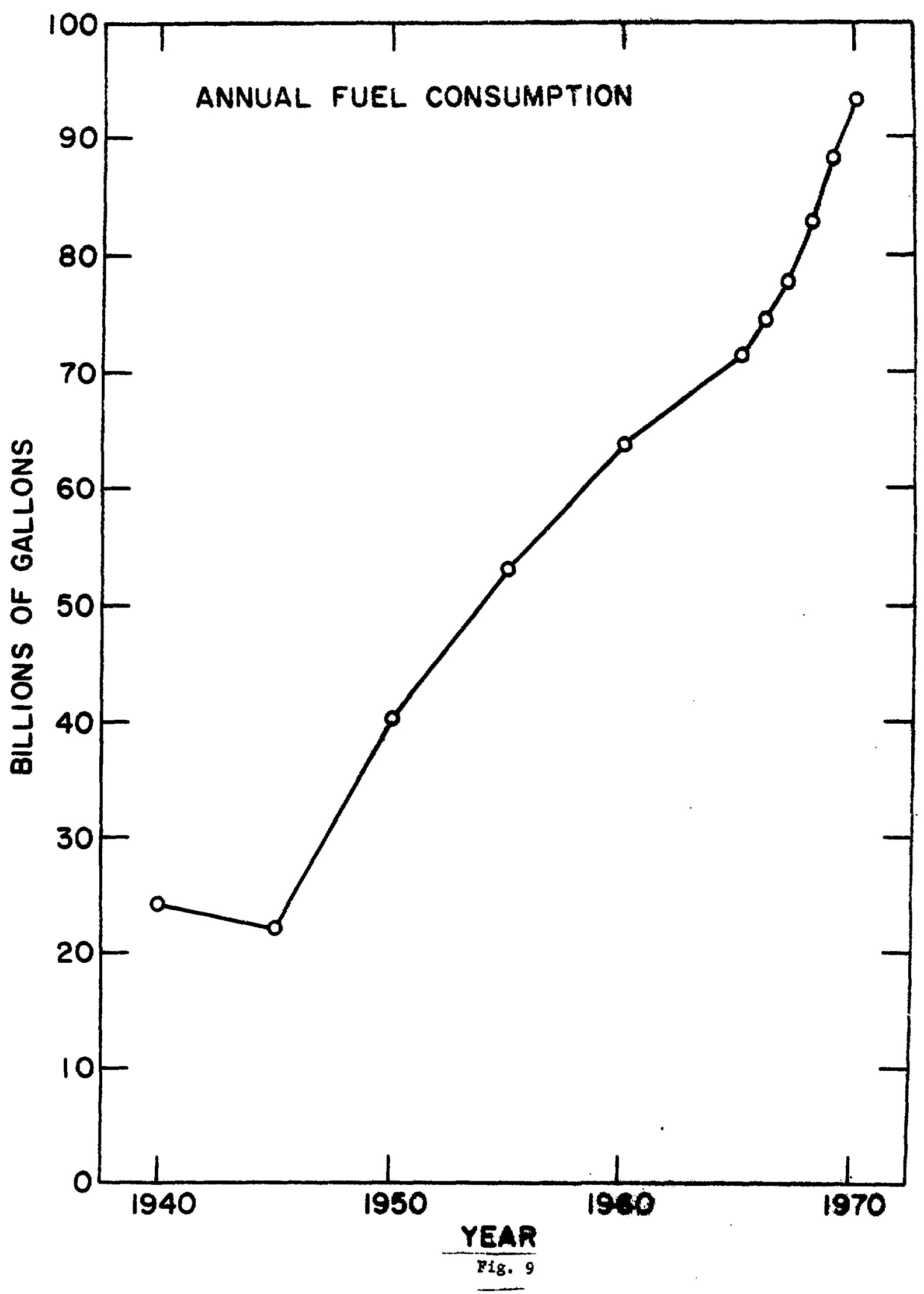


APPENDIX A

POSSIBLE STUDY TOPICS

1. How utilities are regulated.

2. AEC licensing procedures.

3. The New York City Power Crisis.

4. Power pool arrangements.

5. Environmental problems with high voltage transmission lines.

6. Health hazards from air pollution.

7. Health hazards from radiation.

8. Useful applications of waste heat.

9. Cooling towers.

10. Environistatal reports of various utilities.

11. Ecological effects of thermal pollution.

12. Fuel resources of the United States.

13. Breeder reactors.

14. Problems of site selection for power plants.

15. Our national gas supply.

16. Soctal and economic consequences of energy rationing.

17. Can electricity be substituted for gasoline in transportation?

18. Political factors in energy supply.

19. Tax problems.

20. Rate structures in sale of electricity.

21. Improved techniques of coal combustion.

22. Tidal power.

23. Geothermal power.

24. Solar power.

25. Objections to nuclear power.

26. Power supplies for the future (MHD, fuel cells, fusion reactors).

27. Politics of a national energy policy.

28. Hydroelectric possibllities.

29. Pumped storage.

30. The price of safety.

31. Off-shore oll drilling.

32. The Alaskan pipeline.

33. Desalination of water. 
APPENDIX B

APPROXIMATE WHTAGE RATING AN'. HSTIMATED ANNUAL KWHR

CONSTMPIION OF ELECTRICAL APPTIAIDBS - ASSUMING NORMAL USE

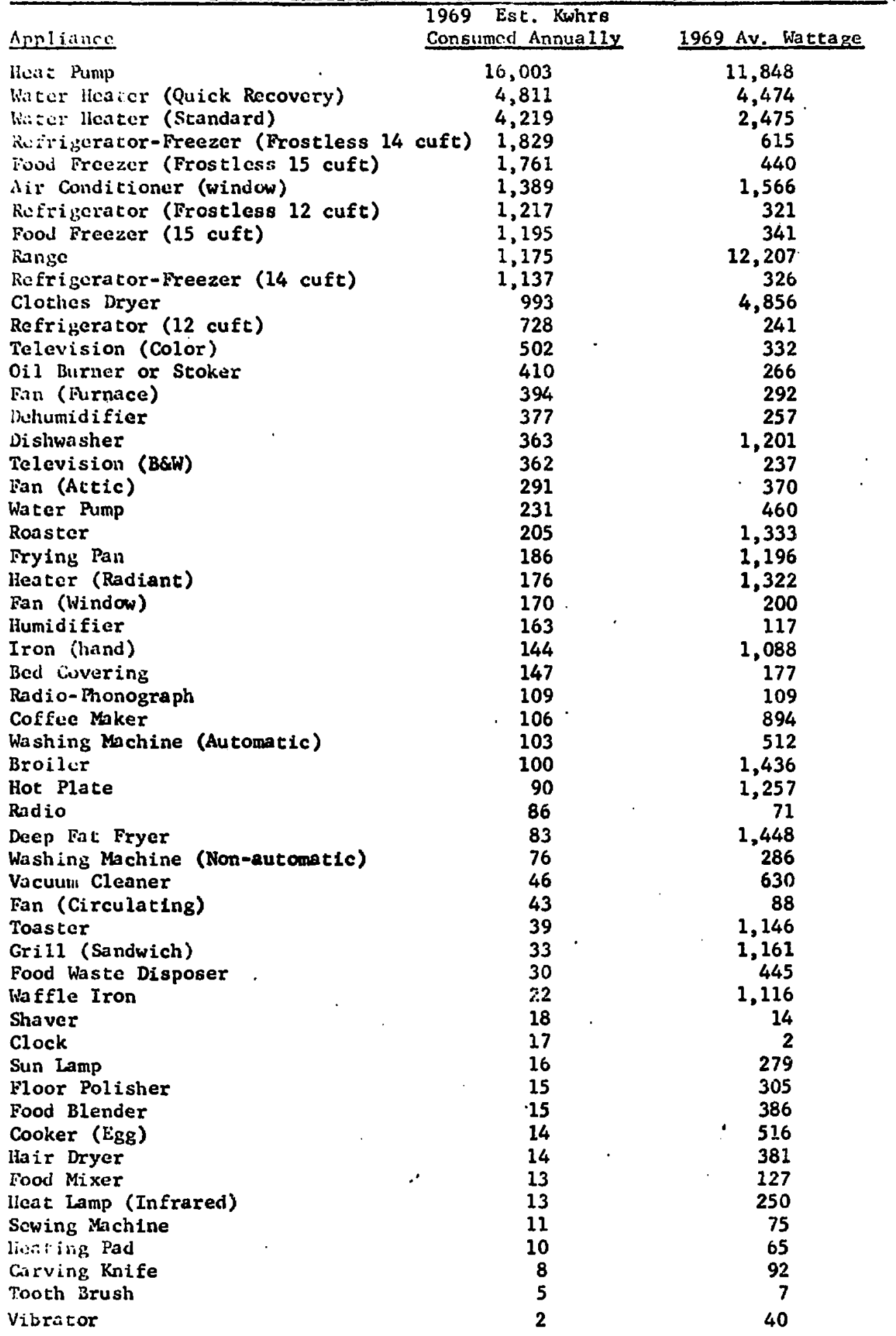

- rc: Llec. Council New England, Statistical Bullecin, 1968. Flgures based on National Averages prepared by The Edison Electric Institute 


\section{APRENDIX C}

CONVERSION FACTORS AND ENERGY EQUTVALEATS

\section{Conversion Fectors}

I $\mathrm{Kw}-\mathrm{hr}(\mathrm{Kwh})=3412.8 \mathrm{Btu}$

1 wyr-yr $\quad=2.992 \times 10^{10} \mathrm{Btu}$

1 tP-hr $\quad=2545$ Btu $=1.98 \times 10^{6} \mathrm{ft}-1 \mathrm{~b}=2.685 \times 10^{6}$ Joules

1 Watt-hr $=3600$ Joules

$1 \mathrm{kP} \quad-0.7455 \mathrm{kw}=1 \mathrm{HP}=550 \mathrm{ft}-1 \mathrm{~b} / \mathrm{sec}$

\section{Energy Equivalents}

The energy content of most fuels can vary depending on thetr source. The following energy equivalents have been used in this report. COAI
Anthracite
$25.4 \times 10^{6} \mathrm{Btu} / \mathrm{ton}$
Bituninous
$26.2 \times 10^{6}$ Btu/ton
Sub-bituminous
$19.0 \times 10^{6}$ Btu/ton
Ifgnite
$13.4 \times 10^{6} \mathrm{Btu} / \mathrm{ton}$

The average heating value of bituminous coal and lignite exported and used in electricity generation and in industrial sectors in 1969 was $24.7 \times$ $10^{6} \mathrm{Btu} / \mathrm{ton}$ (from U.S. Dept. of the Interlor, Bureau of Mines, Maneral Industry Survey", Weekly Cosl Report No. 2839, Feb 11, 1972). 


\section{PETROLEUYY}

Crude Petroleum

Restdual Fuel 011

Dist1llate Fuel oil

Gasoline (Including aviation)

Jet Fuel (Rerosine-type)

Jet Duel (aphetha-type)

Rerosine

Patroleum Coke

Asphalt and Road 011

MUURAL Gas (DRY):

MrURAL GAS (NET)

merrat gas liquids (avg.)

FISSTONABLE MATERTAL
$5.60 \times 10^{6} \mathrm{Btu} / 42 \mathrm{gel}$ barrel

$6.29 \times 10^{6} " 11 "$

$5.83 \times 10^{6}$ " $"$ "

$5.25 \times 10^{6} " 11 "$ "

$5.67 \times 10^{6}$ " " "

$5.36 \times 10^{6}$ " " "

$5.67 \times 20^{6}$ " 11 "

$6.02 \times 10^{6}$ " $11 "$

$6.64 \times 10^{6} " 11 "$

$1031 \mathrm{Btu} / \mathrm{ft}^{3}$ at SIP

1103 " " "

$4.2 \times 10^{6}$ ztu/42 gel barrel

$74.0 \times 10^{6} \mathrm{Btu} / 8 \mathrm{U}-235$ fleatoned

(baaed on 192 Viv fiselon) 
Table I: Scheduled Operational Dates and Capacitles of Nuclear Power Planrs under Construction(2). 1970 1s shown for reference.

\begin{tabular}{cccc}
\hline Year & $\begin{array}{c}\text { Number } \\
\text { of Plants }\end{array}$ & $\begin{array}{c}\text { Total } \\
\text { Capacity } \\
\text { (Millions of } \\
\text { Xilowatts) }\end{array}$ & $\begin{array}{c}\text { Average } \\
\text { Capacity } \\
\text { (Kegawatts) }\end{array}$ \\
\hline$(1970)$ & $(4)$ & $(2.7)$ & $(664.0)$ \\
1971 & 12 & 8.9 & 741.5 \\
1972 & 19 & 16.1 & 849.5 \\
1973 & 16 & 14.9 & 934.1 \\
1974 & 10 & 9.1 & 907.0 \\
\hline
\end{tabular}

Number and Total Capacity of Nuchar Plants Ordered in Recent Years in the U. S. $(3)$.

\begin{tabular}{lcc}
\hline Year & $\begin{array}{c}\text { Mumber of } \\
\text { Plants } \\
\text { Osdered }\end{array}$ & $\begin{array}{c}\text { Total Capacity } \\
\text { (Nillions of } \\
\text { Kilowatts) }\end{array}$ \\
\hline 1966 & 20 & 16.3 \\
1967 & 31 & 25.9 \\
1968 & 16 & 14.8 \\
1969 & 7 & 7.3 \\
1970 & 14 & 14.4 \\
1971 (Jan-Sept) & $22{ }^{(6)}$ & 22.5 \\
\hline
\end{tabular}

Projected Nuclear Share of Total Primary Energy and of Electrical Output, United States $1970-1985^{(3)}$.

\begin{tabular}{ccc}
\hline Year & $\begin{array}{c}\text { Nuclear Share } \\
\text { Primary Energy* }\end{array}$ & $\begin{array}{c}\text { Nuclear Share } \\
\text { Electrical Output }\end{array}$ \\
\hline 1970 & $0.3 \%$ & $1.6 \%$ \\
1975 & 4.0 & 17.6 \\
1980 & 9.3 & 39.1 \\
1985 & 17.2 & 48.0 \\
*Primary nuclear energy will be converted to electri- \\
city at an average efficiency of approximately 35\%.
\end{tabular}


TABLE II: Typical Chalacteristics and Operating Parameters of Comercial power Reactors. $^{\text {a }}$ The properties 1 isted are for a 1000 Me capacity.

PROPERTY $\quad$ BWR $\quad \underline{\text { PWR }}$, HTTRR $^{\mathrm{b}}$

FUER

\begin{tabular}{|c|c|c|c|}
\hline Compound & $\mathrm{BO}_{2}$ & $\mathrm{UO}_{2}$ & $\mathrm{UC}_{2}-\mathrm{ThC}_{2}$ \\
\hline$v^{235}$ Enrichment & 22 & $3.2 \%$ & (Fully Enriched) \\
\hline $\begin{aligned} \text { Pellet size: } & \text { height } x \text { diam- } \\
& \text { eter }\left(i n_{0}\right)\end{aligned}$ & $0.58 \times 0.48$ & $0.60 \times 0.37$ & (see text) \\
\hline Length of Fuel Pin (ft.) & 12 & 12 & (See text) \\
\hline Spacing Becween Fuel Pins (In.) & 0.74 & 0.56 & (See text) \\
\hline Number of PIns Per Element & 49 & 204 & (See text) \\
\hline Total Number of Elements & 764 & 193 & 3841 \\
\hline Total Fuel Welght (Tons) & 186.1 & 108.3 & $2.3\left(u^{235}\right)$ \\
\hline $\begin{array}{c}\text { Core Size: heightxdiameter } \\
\text { (ft.) }\end{array}$ & $12 \times 15.6$ & $12 \times 11.1$ & $15.6 \times 31.1$ \\
\hline $\begin{array}{l}\text { Conversion Ratio } \\
\text { HBREDPYNAMIC }\end{array}$ & 20.5 &, 20.5 & 20.75 \\
\hline Coolant Inlet Temp $\left({ }^{\circ} F\right)$ & 376 & 545 & 758 \\
\hline Coolant Exit Temp $\left({ }^{\circ} \mathrm{E}\right)$ & 546 & 610 & 1449 \\
\hline Reactor Vessel Pressure (psia) & 1050 & 2235 & 700 \\
\hline Net Plant Efficlency & 32.8 & 32.5 & 40.7 \\
\hline
\end{tabular}

a Data were obtained from ref. 5 .

b The HTGR data correspond to a "scaled-up" Fort Saint Vrain reactor (ref. 6). 
IABLE III. BWR-Type Commercial Nuclear Power Stations in the United States (ref. 7 ). Only those plants which are operating or expected to be in operation before the end of 1972 are listed. Experimental and "damonstration" plants which have fulfilled their function and have been shutdown are not 1isted.

\begin{tabular}{|c|c|c|c|c|}
\hline Name & Location & $\begin{array}{l}\text { Blectric } \\
\text { Power } \\
\text { (qwe) } \\
\end{array}$ & $\begin{array}{l}\text { Therwal } \\
\text { Power } \\
\text { (ewe) } \\
\end{array}$ & $\begin{array}{l}\text { Year of } \\
\text { Start-Up }\end{array}$ \\
\hline Dresden $¥ 1$ & Morris, Ill. & 200 & 700 & 1959 \\
\hline Big Rock Point & Big Rock Point, Mich. & 70.3 & 240 & 1962 \\
\hline Bumbolt Bay $\$ 3$ & Eureka, Calff. & 68.5 & 240 & 1963 \\
\hline LaCrosse & Genos, Wis. & 50 & 165 & 1967 \\
\hline Oyster Creek \$1 & Toms River, N.J. & 650 & 1930 & 1969 \\
\hline uine Mile Point & Scrtbe, N.Y. & 625 & 1850 & 1969 \\
\hline Dresden $\$ 2$ & Morris, IIl. & 809 & 2527 & 1970 \\
\hline Millstone +1 & Waterford, Conn. & 652 & 2011 & 1970 \\
\hline Honticello & Monticello, Minn. & 545 & 1670 & 1970 \\
\hline Dresden $\$ 3$ & Morr1s, I11. & 809 & 2527 & 1971 \\
\hline Browns Fercy \#l & Decatur, Ala. & 1065 & 3293 & 1972 \\
\hline Quad Citles \#1 & Cordova, I11. & 809 & 2511 & 1972 \\
\hline Vermont Yankee & Vernon, Vt. & 514 & 1593 & 1972 \\
\hline Quad Cities $\$ 2$ & Cordova, Ill. & 809 & 2511 & 1972 \\
\hline P1lgrím & Plymouth, Mess. & 655 & 1998 & 1972 \\
\hline cooper & Brownutlle, Neb. & 778 & 2381 & 1972 \\
\hline Peach Botrom $\$ 2$ & Peach Bottom, Pa. & 1065 & 3294 & 1972 \\
\hline Bdwin I. Hatch $\$ 1$ & Baxley, Ga. & 786 & $\stackrel{2436}{\cdot}$ & 1972 \\
\hline
\end{tabular}


TABLE IV. PWR-Type Commercial Nuclear Power Stations in the United States (ref. 7 ). Only those plants which are operating or expected to be in operation before the end of 1972 are 11sted. Experimental and "dewonstration" plants which have fulfilled their function and been shutdown are not listed.

\begin{tabular}{|c|c|c|c|c|}
\hline Name ${ }^{a}$ & Location ${ }^{b}$ & $\begin{array}{l}\text { Power } \\
\text { (kie) } \\
\end{array}$ & $\begin{array}{l}\text { Power } \\
\text { (QUIE) } \\
\end{array}$ & $\begin{array}{l}\text { Year of } \\
\text { Start-Up }\end{array}$ \\
\hline Shippingport & Shippingport, Pa. & 90 & 505 & 1957 \\
\hline Yankee & rowe, Mass. & 175 & 600 & 1960 \\
\hline Indlan Point $\$ 1$ & Buchanan, X.Y. & 265 & 615 & 1962 \\
\hline Sen Onofre 1 & San Clesente, Calif. & 430 & 1347 & 1967 \\
\hline Connecticut Yankee & Bnddun Neck, Conn. & 575 & 1825 & 1967 \\
\hline Robert E-ett Genna 1 & Ontario, H.X. & 420 & 1300 & 1969 \\
\hline B. B. Robinson 2 & Bartsullle, S.C. & 700 & 2200 & 1970 \\
\hline PoInt Bexch 1 & Ino Creaks, Wis. & 297 & 1518 & 1970 \\
\hline Palicades 1 & South Baven, MHch. & 700 & 2212 & 1972 \\
\hline Oconet $\$ 1$ & senece, s.C. & 841 & 2452 & 1972 \\
\hline Indian point $\$ 2$ & Duchanan, M.X. & 873 & 2758 & 1972 \\
\hline Surry 1 & Gravel weck, Va. & 780 & 2441 & 1972 \\
\hline Tuxirey. Point $\$ 3$ & Turkey Point, Fla. & 693 & 2200 & 1972 \\
\hline Point Deseh 12 & Ino Creeke, His. & 497 & 1518 & 1972 \\
\hline $2100 \div 1$ & Z100, I11. & 1050 & 3250 & 1972 \\
\hline Dconee 12 & Serece, S.C. & 886 & 2568 & 1972 \\
\hline Three ufle Island $\$ 1$ & Coldabora, Ra. & 831 & 2452 & 1972 \\
\hline Ft. Calboun 1 & Ft. Calhoun, Kab. & 457 & 1420 & 1972 \\
\hline Surxy 2 & Gravel Iack, Va. & 780 & 2441 & 1972 \\
\hline Sale 1 & selem, M.J. & 1050 & 3250 & 1972 \\
\hline
\end{tabular}


TABLE IV (continued)

\begin{tabular}{|c|c|c|c|c|}
\hline Nome ${ }^{a}$ & Location ${ }^{b}$ & $\begin{array}{l}\text { Blectric } \\
\text { Power } \\
\text { (exie) } \\
\end{array}$ & $\begin{array}{c}\text { Thermel } \\
\text { Power } \\
\text { (cuts) }\end{array}$ & $\begin{array}{l}\text { Year of } \\
\text { Start-Up }\end{array}$ \\
\hline Turkey Point 4 & Turkey Polnt, Ble. & 693 & 2200 & 1972 \\
\hline Parle Island $\$ 1$ & Red wing, utnn. & 530 & 1650 & 1972 \\
\hline MaIne Yankee & Hiscasset, Me. & 790 & 2440 & 1972 \\
\hline rewaunee & Carlton, Wis. & 540 & 1650 & 1972 \\
\hline Crystal River $\$ 3$ & Red Level, Ela. & 858 & 2452 & 1972 \\
\hline Rancho Seco $* 1$ & Ciay station, Calif. & 804 & 2452 & 1972 \\
\hline Calvert Cl1ffs 1 & Lusby. kd. & 845 & 2570 & 1972 \\
\hline Donald C. Cook $\$ 1$ & Bridgman, Kilch. & 1054 & 3250 & 1972 \\
\hline Beaver Valley 1 & Maldland, Pa. & 847 & 2660 & 1972 \\
\hline Ariansas 11 & London, Ark. & 820 & 2452 & 1972 \\
\hline
\end{tabular}

aly the Identifying words In the formal nane have been given. Wost are called, " : muclear Power station, Unit 10. 1", or equivalent. Often fossil fuel units are located at the same site and are assigned unit numbers, e.g. Turkey Point Station, Units 1 and 2 are fossil whereas 3 and 4 are nuclear.

b Since sost plants are sited in remote areas, the locution is somatines given as the neares: population center or In terms of sose proninent geographical feature. Locations cited here are those listed in the AEC licensing dockets. 
TABLE V. Miscellaneous Comerical Nuclear Power Stations in the United states. The table Includes only those operating or scheduled to begin operating in 1972 , and onits several amall demonstration plants which have sarved their function and been shut-down and disantled.

\begin{tabular}{|c|c|c|c|c|c|}
\hline mane ${ }^{a}$ & Location & Iype & $\begin{array}{c}\text { Blectric } \\
\text { Power } \\
\text { Yile } \\
\end{array}$ & $\begin{array}{c}\text { Thermal } \\
\text { Power } \\
\text { yist } \\
\end{array}$ & $\begin{array}{l}\text { Year of } \\
\text { Start-Up }\end{array}$ \\
\hline Bnrico Fermi & Lagoona Beach, Mich. & Sodium Cooled Fast & 60.9 & 200 & 1963 \\
\hline a Reactor & Richland, Wesh. & $\begin{array}{l}\text { Gxaphite dual pur- } \\
\text { pose }\end{array}$ & 790 & 4000 & 1963 \\
\hline Peach Bottom \$1 & Pesch Botton, Pa. & Exte: & 40 & 115 & 1966 \\
\hline Fort st. Vrain & Plattevi1le, col. & traen & 330 & 842 & 1972 \\
\hline
\end{tabular}

- Oaly the 1dentifylng words in the formal nama have been given. Wost are called, "Ihelear power station, Unit Mo. 1", or equivelent. often fossil fuel units are loceted at the sare site and are assigand unit nubers, e.g. Turkey Point station, Units 1 and 2 are fosell wheress 3 and 4 are nuclear.

b since nost plants are sited in repote eress, the location is sometimes given as the nearest population center or In terus of sone proninent geographical feature. Locations eited here are those 1isted in the AEC licensing dockets. 
TABIE VI

ESTIMATE OF U.S. POPULATION RADIATION DOSE

(Source: EPA)

Doses in Million Man-Rems Per Year

\begin{tabular}{|c|c|c|c|c|c|}
\hline \multirow[b]{3}{*}{ Natural } & \multirow[b]{3}{*}{ Background } & \multicolumn{4}{|c|}{ Doses in Million Man-Rems Per Year } \\
\hline & & \multicolumn{2}{|c|}{1970} & \multicolumn{2}{|c|}{2000} \\
\hline & & 26.6 & $(63.0 \%)$ & 41.7 & $(62.7 \%)$ \\
\hline Medical & $x$-Rays & 14.8 & $(35.1 \%)$ & 23.1 & (34.7\%) \\
\hline Weapons & Tests & 0.8 & ( 2.0\%) & 1.6 & (2.47) \\
\hline Nuclear & Power & 0.004 & $(0.01 \%)$ & 0.14 & $(0.2 \%)$ \\
\hline & TOTALS & 42.2 & & 66.5 & \\
\hline
\end{tabular}

U. S. Population (Millions) 205

321

Horld Nuclear Capacity (GWe) 20

2000 
TABLE VII

Estimated Radiation Dose from Proposed Shoreham Nuclear Power Plant ${ }^{*}$

IOCATION

"FENCE-POST" (at Site Boundary)

Average Fopulation Exposure within 50-mile radius of plant

Average U.S. Population Exposure 1970 from 17 operating nuclear power plants

Average U.S. Population Exposure in year 2000 from $\sim 200$ operating nuclear power plants and fuel processing plants

* Based on Fublic Health Service surveys at Dresdan I Nuclear Power Station.

'Public commitment by Iong Island Lighting Co. that "fence-post" dose will be maintained at $1 \%$ or less of A.E.C. guidelines.
DOSE

5 mrem/year ${ }^{\dagger}$

$0.005 \mathrm{mrem} /$ year

less than $0.001 \mathrm{mrem} /$ year

less than 0.1 mrem/year 


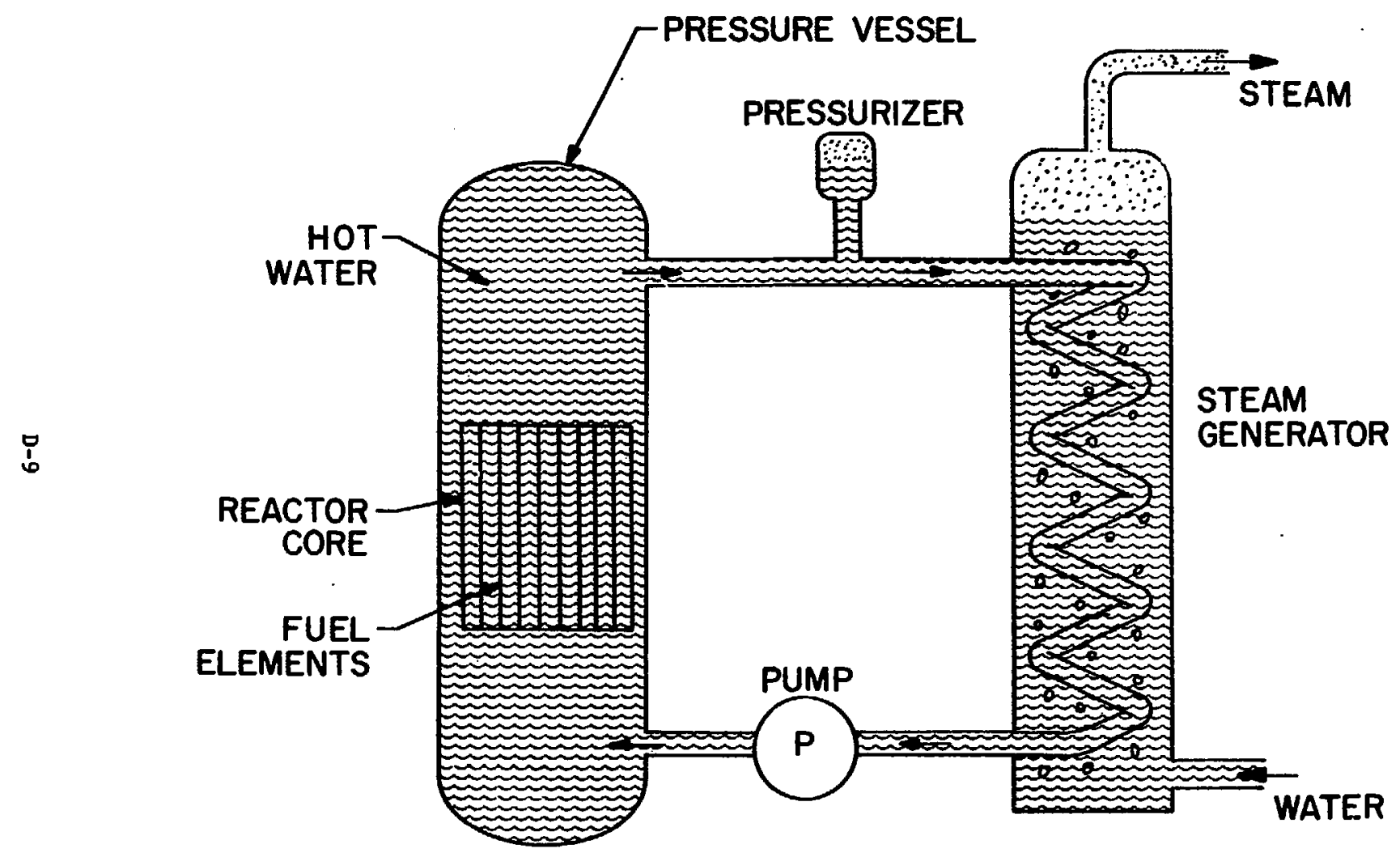

Fig.2: Schematic of a Pressurized Water Reactor (PWK) 


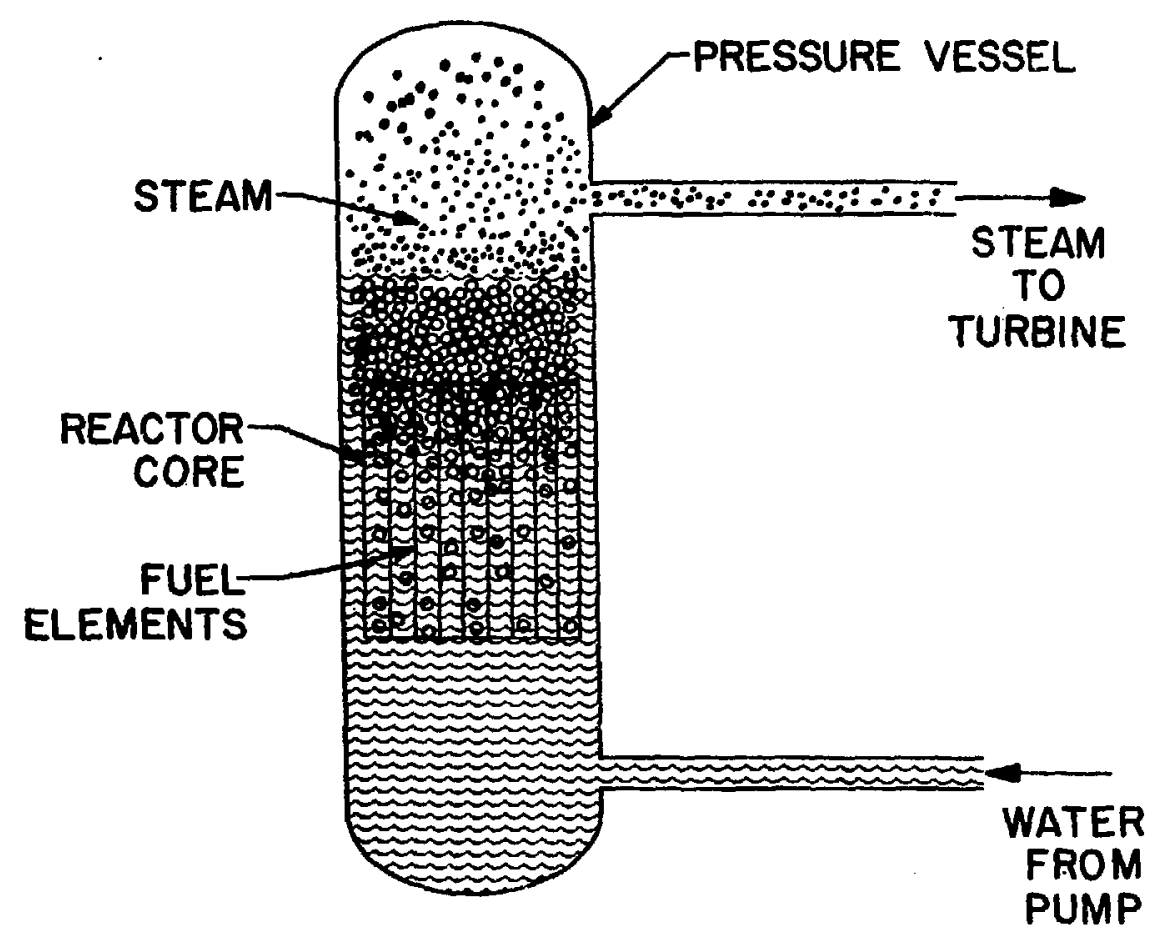

Fig. 1: Schematic of a Boiling Water Reactor (BWR) 


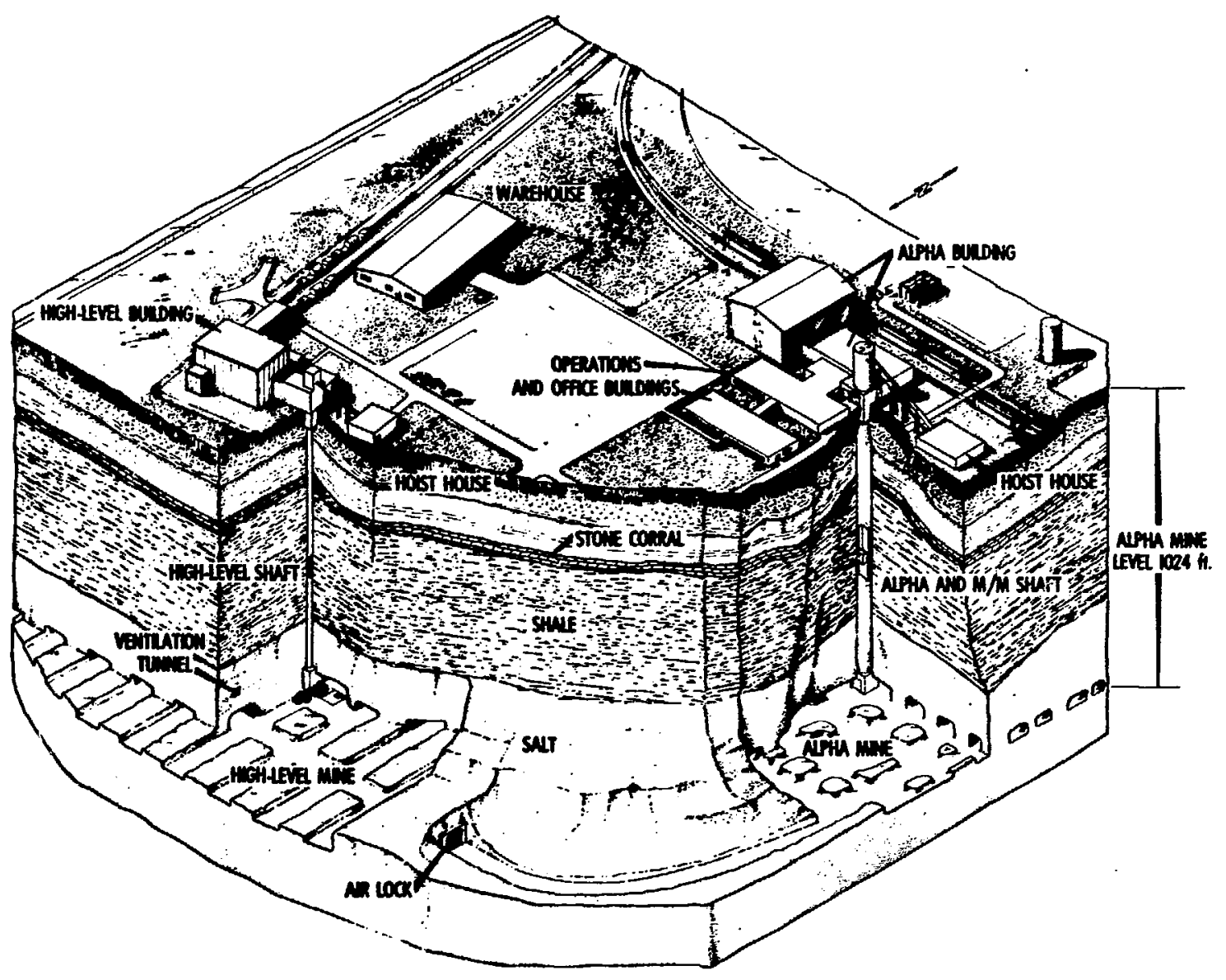

FEDERAL REPOSITORY

Fig. 3: Schematic of proposed Bedded Salt Repository for Storage of Radioactive Wastes 
Thorium Breeding Cycle

$$
\begin{aligned}
& \mathrm{U}^{233}+\mathrm{n} \stackrel{\text { fission }}{\longrightarrow} 2.2 \mathrm{n}+\text { fission products }+190 \mathrm{MeV} \\
& \mathrm{Th}^{232}+\mathrm{n} \stackrel{\leftrightarrow}{\rightarrow} \mathrm{Th}^{233}(22.2 \mathrm{~m}) \stackrel{\beta^{-}}{\longrightarrow} \mathrm{Pa}^{233}(27 \mathrm{~d}) \stackrel{\beta^{-}}{\longrightarrow} \mathrm{U}^{233}\left(1.6 \times 10^{5} \mathrm{y}\right)
\end{aligned}
$$

$\stackrel{\leftrightarrow}{u}^{u}$

Uranium-238 Breeding Cycle

$$
\mathrm{U}^{238}+\mathrm{n} \stackrel{\mathrm{Pu}^{239}+\mathrm{n} \stackrel{\text { fission }}{\longrightarrow} 2.8 \mathrm{n}+\text { fission products }+200 \mathrm{MeV}}{\stackrel{\mathrm{U}^{239}}{\longrightarrow}(23.5 \mathrm{~m}) \stackrel{\beta^{-}}{\longrightarrow} \mathrm{Np}^{239}(2.35 \mathrm{~d}) \stackrel{\beta^{-}}{\longrightarrow} \mathrm{Pu}^{239}\left(2.44 \times 10^{4} \mathrm{y}\right)}
$$

